\title{
REFORMA DO MARCO LEGAL DO TERCEIRO SETOR NO BRASIL"
}

\author{
PAUlo MODESTo**
}

\begin{abstract}
1. Introdução. 2. Vantagens e Desvantagens da Concessão de Títulos Juridicos Especiais a Entidades do Terceiro Setor. 3. Crise do Título de Utilidade Pública. 4. O Título de Organização Social. 5. O Título de Organização da Sociedade Civil de Caráter Público. 6. Resumo.
\end{abstract}

\section{Introdução}

As entidades constituídas com personalidade jurídica privada, mas de fins públicos, também conhecidas como entidades do terceiro setor, são tradicionalmente identificadas pela legislação brasileira como entidades de utilidade pública. Para o leigo, a denominação entidade de utilidade pública, à semelhança da recente denominação organização social, designa uma espécie de entidade, uma forma especial de organização, reconhecível prontamente no plano da realidade sensível. Mas se trata de uma ilusão lingüística. Essas designações consistem apenas em títulos jurídicos. Em princípio, títulos jurídicos que podem ser conferidos, suspensos ou retirados. Essas expressões não traduzem uma forma de pessoa jurídica privada. Nem informam uma qualidade inata ou traço original de qualquer espécie de enti-

- Texto escrito para publicação em coletânea organizada pela UNESCO - Organização das Naçōes Unidas para a Educação, a Ciência e a Cultura, dentro do projeto Revisão da Estrutura Jurídica e Normativa do Terceiro Setor, cuja coordenação é chefiada no Brasil pelo Prof. Joaquim Falcão. Agradeço aos coordenadores do projeto a autorizaçāo para publicação isolada do texto em revistas jurídicas especializadas.

** Professor de Direito da Universidade Federal da Bahia. Professor e Coordenador do Curso de Especialização em Direito Público da UNIFACS. Ex-Assessor Especial do Ministro da Administração Federal e Reforma do Estado para a Reforma Constitucional (1995-1998). Membro do Ministério Público do Estado da Bahia, do Instituto Brasileiro de Direito Administrativo e do Instituto de Advogados do Estado da Bahia. Conselheiro Técnico da Sociedade Brasileira de Direito Público. E-mail: paulomodesto@yahoo.com 
dade. Dizer de alguma entidade que ela é "de utilidade pública" ou "organização social" significa dizer que ela recebeu e mantém o correspondente título jurídico.

No Brasil, recentemente, instalou-se com intensidade incomum o debate sobre a utilidade e a adequação à realidade dos nossos dias do tradicional título de utilidade pública. Discussões dentro e fora do aparelho do Estado, envolvendo inclusive entidades do terceiro setor, propuseram saídas para o que pode ser denominado como a crise do título de utilidade pública. Algumas saídas ganharam a forma de lei (v.g., Lei n. 9.637, de 15 de maio de 1998 - Organizações Sociais); outras, constam em projetos de lei em discussão no Congresso Nacional (v.g., Projeto de Lei n. 4.690, apresentado em 28 de agosto de 1998 - Organizações da Sociedade Civil de Caráter Público).

A discussão da matéria admite ângulos distintos de análise (administrativo, econômico, político, jurídico, histórico, social etc.). No aspecto jurídico, no entanto, a discussão não apenas tem sido limitada, com poucos estudos sobre o tema, mas também restrita a uma interpretação do conteúdo da legislação existente, com vista a aplicação do direito vigente. No momento, porém, além da tarefa de compreensão para aplicação, tradicional entre os juristas, parece fundamental realizar também o que se tem denominado avaliação da legislação (CHEVALLIER, 1992:18-22; ATIENZA, 1997:64 e segs.). Nesta última abordagem, a atenção do jurista técnico não se concentra na fase da aplicação da norma legal, mas na fase de sua elaboração (avaliação legislativa ex ante) ou na fase subseqüente dos efeitos por ela produzidos ou a produzir (avaliação legislativa ex post).

É comum dizer-se que a avaliação legislativa é tarefa não jurídica. Essa afirmação envolve, no entanto, uma dupla incompreensão. Primeiro, uma incompreensão sobre o papel dos juristas. Segundo, uma incompreensão sobre as formas de avaliação da legislação vigente ou em estado de produção.

Os juristas não são (ou não devem ser) simples leguleios da lei. Não são simples espectadores do processo legislativo. O saber dos juristas é um saber de protagonistas, pois mediante o discurso dos juristas são estabelecidas decisōes ou condições para a tomada de decisões jurídicas. Isso ocorre porque, enquanto a maior parte das ciências opera com um objeto dado, que o cientista pressupõe como uma unidade estável, o objeto do jurista é um objeto lingüístico, socialmente condicionado, que se elabora e apresenta ao domínio público mediante a decisão interpretativa. Esta é a razão de se dizer, não sem algum exagero, que o objeto do saber do jurista não é algo dado ao seu conhecimento, mas o resultado do seu labor. Sobremais, os juristas tendem a ser vistos como agentes sociais que monopolizam o discurso técnico sobre as normas da coletividade, com condições de antecipar as conseqüências negativas $e$ positivas da aplicação das normas jurídicas aprovadas ou em fase de aprovação, propor novas pautas de solução de conflitos, bem como capacidade de enquadrar de forma argumentativa os novos conflitos no interior do direito já existente, enfraquecendo ou eliminando temporariamente conflitos (FERRAZ JR., 1994: 280-1; 1980:149 e segs.; MODESTO, 1997:197-8).

De outra parte, a avaliação da legislação não precisa ser limitada a meras apurações empíricas, realizadas com o instrumental da sociologia geral ou jurídica, da ciência política ou da administração, com vistas a determinar se os objetivos da 
norma legal foram atendidos (eficácia prática da norma), apurar qual a sua específica relação de custo-benefício (eficiência da norma) ou o grau de adesão que ela obtém do público (grau de legitimação). Faz-se também avaliação legislativa quando se apura a compatibilidade entre os propósitos declarados na norma e o resultado normativo final, bem como a congruência dos objetivos normativos com as possíveis conseqüências da inteira aplicação do modelo legal.

Neste trabalho, procurando utilizar uma linguagem acessível, esboço uma breve avaliação sobre a crise do título de utilidade pública, bem como sobre a concordância dos novos títulos jurídicos (o título de organização social e o título de organização da sociedade civil de caráter público) face aos propósitos que enunciam. Tenta-se sugerir, ainda, soluções técnicas para correção de lacunas e inconsistências percebidas nos dois últimos títulos referidos, com vistas ao seu aperfeiçoamento. Este trabalho, de certo modo, continua a exploração do tema sobre o marco legal do terceiro setor iniciada em artigo anterior (MODESTO, 1997). No entanto, ao contrário do artigo referido, este trabalho propõe uma discussão avaliativa dos resultados alcançados com os textos normativos disponíveis no plano da União e não uma discussão analítica do tema. Mas não se abandona por completo a perspectiva analítica; o texto inicia exatamente com uma análise das vantagens e desvantagens da concessão de títulos jurídicos especiais a entidades do terceiro setor. Trata-se de tarefa que não é isenta de dificuldades, mas que parece urgente empreender.

\section{Vantagens e desvantagens da concessão de títulos jurídicos especiais a entidades do terceiro setor}

A concessão caso a caso de títulos jurídicos especiais a entidades do terceiro setor parece atender a pelo menos três propósitos. Em primeiro lugar, diferenciar as entidades qualificadas, beneficiadas com o título, relativamente às entidades comuns, destituídas dessa especial qualidade jurídica. Essa diferenciação permite inserir as entidades qualificadas em um regime jurídico específico. Em segundo lugar, a concessão do título permite padronizar o tratamento normativo de entidades que apresentem caracteristicas comuns relevantes, evitando o tratamento legal casuistico dessas entidades. Em terceiro lugar, a outorga de títulos permite o estabelecimento de um mecanismo de controle de aspectos da atividade das entidades qualificadas, flexível por excelência, entre outras razões, porque o título funciona como um instrumento que admite não apenas concessão, mas também suspensão e cancelamento.

A realização desses propósitos, necessariamente interrelacionados, em princípio pode ser vista como vantajosa e reveladora das funçōes desempenhadas pelos títulos jurídicos, em especial as funções de certificação, padronização e controle jurídico. Sem dúvida, as entidades que recebem o título são vistas como entidades certificadas, que possuem uma qualidade jurídica específica, o que usualmente lhes garante um regime de benefícios e apoios especiais previstos na lei apenas para as entidades qualificadas. Passam a receber enquadramento jurídico distinto do comum, pelo simples fato de receberem ou manterem o título especial. Em princípio, salvo pre- 
visão legal, esse título independe de um juízo sobre o mérito da atuação da entidade, relacionando-se apenas com o atendimento dos requisitos de concessão do título e com o atendimento das exigências de manutenção de título, se houver. Por outro lado, a concessão de um título padrão libera o legislador da tarefa de criar a cada momento vantagens e benefícios ad hoc, de forma isolada, em favor de entidades que exercitem atividades de interesse coletivo. $O$ legislador limita-se a fixar benefícios e obrigações especiais para um número indeterminado de entidades da sociedade civil, presentes e futuras, furtando-se a uma atuação casuística. Por fim, na medida em que o título assume o papel de veículo que introduz a entidade no regime jurídico especial, mais favorável, vem a servir também de instrumento no controle das entidades qualificadas, pois aquelas que se desviam de suas missões podem ser penalizadas com a cassação ou suspensão do título, perdendo as vantagens anteriormente usufruídas. Neste regime, não há direito adquirido ao título, ou às vantagens a ele associadas, conformadoras do regime jurídico especial, quando a entidade viola as exigências de sua válida manutenção.

Mas existem também desvantagens que podem ser associadas ao mecanismo de concessão de títulos jurídicos especiais a entidades do terceiro setor. São efeitos perversos, efeitos eventuais ou não desejados dessa técnica jurídica, mas que não podem ser desconsiderados por completo. Para simplificar, vinculo-os às funções básicas dos títulos jurídicos. Assim, ligado à função de certificação surge a possibilidade de certificação indevida, realizada sem critério, por ato administrativo ou lei casuística, como perversão de muitas vezes difícil controle. A concessão graciosa e indevida do título pode revelar tanto a frouxidão dos critérios utilizados para reconhecimento do título pela autoridade competente quanto hipótese de clara fraude, violação intencional do modelo legal geral na matéria. A reiteração de certificações indevidas produz com o tempo uma erosão da credibilidade do título, pois este deixa de servir efetivamente como instrumento de identificação de uma certo tipo de entidade, para ser confundido com uma simples exigência legal. As entidades são divididas em "autênticas" e "inautênticas", independentemente de possuírem ou não o título, perdendo este em parte a sua função de certificação, ao menos para fins simbólicos. A segunda desvantagem da técnica, ou perversão possível do modelo, é o risco da padronização excessiva de vantagens e obrigações legais para entidades distintas. Isso ocorre quase inevitavelmente quando as exigências para concessão do título são muito genéricas, isto é, quando a lei não cuida de realizar distinções importantes e adota uma formulação excessivamente abrangente. Neste caso, o título deixa de ser visto como útil ou adequado por segmentos do terceiro setor, perdendo atratividade e estimulando a criação de novos títulos. A terceira desvantagem da técnica de concessão de títulos é a margem de insegurança juridica que essa técnica embute. Na medida em que a manutenção do título está condicionada geralmente ao cumprimento continuado de certas exigências, que são periodicamente aferidas pela autoridade competente, a entidade qualificada encontra-se periodicamente sujeita a eventual ocorrência de desvios no sistema de controle, com graves repercussōes na sua condição jurídica enquanto sujeito de direitos e obrigações. Esse problema ou risco é maior na ausência de uma previsão normativa clara sobre o modo de processamento do controle administrativo exigido para a continuidade do título, máxime 
quando faltam normas que assegurem às entidades garantias contra o exercício abusivo ou persecutório da prerrogativa de controle pela autoridade. Algumas dessas desvantagens e perversões encontramos exemplarmente realizadas pelo título de utilidade pública.

\section{Crise do título de utilidade pública}

A discussão atual sobre novos títulos jurídicos para as entidades da sociedade social de fins públicos é incompreensível sem a percepção da crise do título de utilidade pública, regido no plano federal ainda a partir fundamentalmente da Lei $\mathrm{n}$. 91, de 28 de agosto de 1935, alterada em aspectos secundários ao longo do tempo, por um lado, e, por outro, da crise também do modo de atuação do Estado nos serviços sociais.

É sabido que o Estado atualmente não tem condições de monopolizar a prestação direta, executiva, do todos os serviços sociais de interesse coletivo. Estes podem ser executados por outros sujeitos, como associações de usuários, fundações ou organizações não governamentais sem fins lucrativos, sob acompanhamento e financiamento do Estado. Não prover diretamente o serviço não quer dizer tornar-se irresponsável perante essas necessidades sociais básicas. Não se trata de reduzir o Estado a mero ente regulador. $O$ Estado apenas regulador é o Estado Mínimo, utopia conservadora insustentável ante as desigualdades das sociedades atuais. Não é este o Estado que se espera resulte das reformas em curso em todo o mundo. O Estado deve ser regulador e promotor dos serviços sociais básicos e econômicos estratégicos. Precisa garantir a prestação de serviços de saúde de forma universal, mas não deter o domínio de todos os hospitais necessários; precisa assegurar o oferecimento de ensino de qualidade aos cidadãos, mas não estatizar todo o ensino. Os serviços sociais devem ser fortemente financiados pelo Estado, assegurados de forma imparcial pelo Estado, mas não necessariamente realizados pelo aparato do Estado. Neste contexto, crescem de importância os entes "públicos não-estatais". (BRESSER PEREIRA, 1996: 285-87; 1997: 25-31; CUNIL GRAU, 1996: 126-137). Na verdade, não existe impedimento constitucional algum à assunção por particulares de tarefas e missōes de interesse social em colaboração com a administração pública. Desde de que cumpridos requisitos de salvaguarda do interesse público, mais intensos e onerosos quanto mais ampla for a transferência de encargos e recursos, a cooperação é lícita e até mesmo estimulada pela Constituição da República (MODESTO, 1997: 204-07).

Essa parceria, no entanto, exige na relação do Estado com as organizações não governamentais a ocorrência em grau adequado de confiança e lealdade recíproca, bem como sincera e mútua concordância em torno de propósitos comuns.

São qualidades de relação que devem encontrar assento ou pelo menos ressonância na legislação. Mas não é o que ocorre. A legislação básica sobre utilidade pública no âmbito da União tem sido um dos principais problemas para o fortalecimento do terceiro setor no país. Não por ser detalhista ou limitadora. Mas exatamente pela razão contrária. A legislação básica na matéria, em especial no plano federal, é deficiente, lacônica, deixando uma enorme quantidade de temas sem cobertura 
legal e sob o comando da discrição de autoridades administrativas. Essa lacuna de cobertura facilitou a ocorrência de dois fenômenos conhecidos: (a) a proliferação de entidades inautênticas, quando não de fachada, vinculadas a interesses políticos menores, econômicos ou de grupos restritos; (b) o estímulo a processos de corrupção no setor público.

Este estado de coisas foi facilitado ao longo do tempo por inexistir na legislação federal a diferenciação clara entre entidades de favorecimento mútuo ou de fins mútuos (dirigidas a proporcionar benefícios a um círculo restrito ou limitado de sócios, inclusive mediante a cobrança de contribuições em dinheiro, facultativas ou compulsórias) e as entidades de fins comunitários, de fins públicos ou de solidariedade social (dirigidas a oferecer utilidades concretas ou benefícios especiais à comunidade de um modo geral, sem considerar vínculos jurídicos especiais, quase sempre de forma gratuita). Aos dois tipos de entidade a legislação vigente na matéria confere o mesmo título jurídico, o título de utilidade pública, autorizando e mesmo impondo um tratamento legal mais benéfico (renúncia fiscal, previsão de subvenções sociais, contratação direta etc.), deixando ainda de prever qualquer forma mais efetiva de controle de resultados e satisfazendo-se basicamente com a apresentação periódica de documentos. Este caráter indiferenciado na referência às entidades do terceiro setor (qualificam-se do mesmo modo creches e clubes, escolas comunitárias e escolas privadas pagas etc.) e a debilidade do sistema de controle facilitou a ocorrência de abusos importantes e fomentou a desconfiança em atividades e relações de parceria em que confiança e probidade são valores fundamentais. Recorde-se o "escândalo do orçamento", esquema de malversação de recursos públicos, descoberto por acaso, consistente na utilização por um grupo razoável de parlamentares federais de entidades filantrópicas de fachada, de papel, que eram por eles criadas através de terceiros e por sua ação parlamentar recebiam vultosas somas de recursos públicos sem qualquer compromisso efetivo com atividades relevantes em matéria social ou em benefício da coletividade. É fortalecido, a partir desse episódio, o fraseado segundo o qual existem entidades filantrópicas e "pilantrópicas", neologismo empregado para referir as filantrópicas inautênticas (BARROSO LEITE, 1997: 43). Neste contexto, são criadas condições para uma situação de suspeição generalizada, de indefinição e perplexidade, indiscutivelmente negativa para o desenvolvimento entre os brasileiros de um voluntariado mais efetivo no país e, consequientemente, do próprio terceiro setor no Brasil. Por voluntariado ou serviço voluntário entende-se, conforme recente regulação, "a atividade não remunerada, prestada por pessoa física a entidade pública de qualquer natureza ou instituição privada de fins não lucrativos, que tenha objetivos cívicos, culturais, educacionais, científicos, recreativos ou de assistência social, inclusive, mutualidade" (Lei $\mathrm{n}^{\mathrm{Q}}$ 9.608, de 18.02.98).

\section{O título de organização social}

A Lei n. 9.637, de 15 de maio de 1998, criou no âmbito da União um novo título jurídico, o título de organização social, como uma das respostas à crise do 
título de utilidade pública. A lei estabeleceu os requisitos para investir alguma entidade privada sem fins lucrativos desta qualidade jurídica e diversas normas de relacionamento do Estado com as entidades privadas assim qualificadas, constituídas sob as formas estruturais comuns do direito civil (fundações ou associações). $\mathrm{Na}$ verdade, a denominação organização social, como frisado anteriormente, designa apenas as entidades privadas, fundações ou associações, sem fins lucrativos, que usufruem do título de organização social. De fato, o modelo normativo das organizações sociais não se dedica a criar ou constituir uma nova forma de pessoa jurídica, como muitos afirmam.

As organizações sociais definem-se como instituições do terceiro setor (pessoas privadas de fins públicos, sem finalidade lucrativa, constituídas voluntariamente por particulares, auxiliares do Estado na persecução de atividades de conteúdo social relevante). Mas ser organização social não significa apresentar uma estrutura jurídica inovadora, mas possuir um título jurídico especial, conferido pelo Poder Público em vista do atendimento de requisitos gerais de constituição e funcionamento previstos expressamente em lei. Esses requisitos são de adesão voluntária por parte das entidades privadas e estão dirigidos a assegurar a persecução efetiva e as garantias necessárias a uma relação de confiança e parceria entre a entidade privada e o Poder Público.

O título de organização social, conferido pelo Poder Público, faz incidir sobre as instituições reconhecidas um plexo de disposições jurídicas especiais, que asseguram vantagens e sujeições incomuns para as tradicionais pessoas jurídicas qualificadas pelo título de utilidade pública. Em qualquer dos dois títulos referidos, porém, dá-se um plus à personalidade jurídica das entidades privadas, que passam a gozar de benefícios especiais não extensíveis às demais pessoas jurídicas privadas (benefícios tributários e vantagens administrativas diversas).

A todo rigor, portanto, nenhuma entidade é constituída como organização social. Ser organização social não se pode traduzir em uma qualidade inata, mas em uma qualidade adquirida, resultado de um ato formal de reconhecimento do Poder Público, facultativo e eventual, semelhante em muitos aspectos à qualificação deferida às instituições privadas sem fins lucrativos quando recebem o título de utilidade pública.

Existem indiscutivelmente diferenças e semelhanças entre os títulos de utilidade pública e de organização social.

Os traços comuns são os seguintes:

1) a iniciativa privada voluntária na sua criação e na sua constituição;

2) a existência de limites gerais à livre constituição e funcionamento dos órgãos de direção ou gerência como requisito para o exercício de ato posterior de reconhecimento ou qualificação;

3) a afetação a uma finalidade de interesse público ou socialmente relevante;

4) o recebimento de favores especiais, subsídios, isenções e contribuições do Estado;

5) a submissão a uma vigilância especial e a limitações de ordem administrativa que vão além do simples poder de polícia exercido sobre as demais pessoas privadas; 
6) sujeição ao controle do Tribunal de Contas e à fiscalização do Ministério Público;

7) a necessidade de reconhecimento formal por parte do Estado, segundo um procedimento especial regulado em lei;

8) a destinação legal do patrimônio social a outra entidade de mesma natureza, em caso de extinção da entidade, não sendo permitido seja o patrimônio repartido entre os membros da instituição; e

9) a submissão ao regime jurídico das pessoas de direito privado, com derrogações de direito público.

Os traços diferenciais básicos são os seguintes:

1) os estatutos das organizações sociais devem prever e adotar determinado modelo de composição para os seus órgãos de deliberação superior, inclusive prevendo a participação necessária de representantes do Estado, como requisito para permitir o ato posterior de qualificação pelo Poder Público;

2) o trespasse de bens e recursos públicos nas organizações sociais está condicionado à assinatura de contratos de gestão com os órgãos competentes da administração pública federal;

3) o estatuto da organização social deve prever, também como um requisito da qualificação, sujeição da entidade à publicação anual no Diário Oficial da União do relatório de execução do acordo ou contrato de gestão (relatório gerencial das atividades desenvolvidas, apoiadas pelo Poder Público, e não apenas do relatório formal da contabilidade da entidade);

4) o estatuto deve prever, como requisito de qualificação, regras rígidas de reforma das finalidades sociais, bem como normas para a definição impessoal das regras a serem adotadas para a remuneração do pessoal da entidade e para o sistema de compras;

5) o estatuto ainda deve prever que a entidade estará sujeita a controle externo de resultados, periódicos e a posteriori, realizado por comissão de avaliação composta por especialistas de notória qualificação, especialmente destinado à verificação do cumprimento do contrato ou acordo de gestão firmado com o Poder Público;

6) as entidades qualificadas como organizações sociais poderão utilizar bens materiais e recursos humanos de entidades extintas do Estado, desde que a extinção tenha sido realizada por lei específica;

7) as entidades qualificadas poderāo também absorver atividades e contratos de entidade extintas, também quando autorizados por lei, bem como os seus símbolos designativos, desde que estes sejam seguidos obrigatoriamente do símbolo OS.

Parece evidente, por esta simples enumeração, que o marco legal das organizações sociais procura corrigir alguns dos desvios mais comuns do título de utilidade pública. Neste modelo são estabelecidas exigências adicionais que tentam restringir os estímulos legais apenas a entidades de fins comunitários, auto e hetero-limitadas para a persecução objetiva de fins coletivos. Fecham-se as frestas para a qualificação de entidades de favorecimento mútuo ou de fins mútuos. Neste sentido, consta da lei exigência de adoção de regras impessoais para compras e plano de salários; existência de colegiado superior composto por fundadores, personalidades da comunidade e representantes do poder público; previsão de auditorias gerenciais e controle 
de resultados; fomento público condicionado à assinatura de contrato ou acordo de gestão com o Poder Público, definidor de metas e tarefas a cumprir; responsabilização direta dos dirigentes pela regular utilização dos recursos públicos vinculados ao acordo de gestão, entre outras garantias atualmente não exigidas para o deferimento do título de utilidade pública para as entidades privadas sem fins lucrativos. Ou seja, pelo via da criação de um novo título jurídico (o título de organização social) introduziu-se no sistema legal uma série de novas garantias e cautelas inexistentes no sistema geral das entidades de utilidade pública, sem caráter burocrático ou formalístico, destinadas a preservar de forma abrangente a finalidade pública destas instituições, sem prejuízo das flexibilidades conferidas pela personalidade jurídica de direito privado.

Mas tudo o que vem de ser dito não significa que o modelo abstrato das organizações sociais seja perfeito ou imune a desvios. Embora ainda seja cedo para uma avaliação adequada do modelo, preocupa o fato de terem sido apenas duas as entidades qualificadas como organizações sociais no âmbito da União e idêntica a forma de ambas serem qualificadas. Nos dois casos, a qualificação foi precedida de extinção de entidade ou órgão público e a qualificação recaiu em entidades privadas com pouco tempo de existência, sem serviços comprovados, sem qualquer capital próprio, salvo o capital humano. Essa situação parece revelar a existência de lacunas e inconsistências na lei, que merecem a meu sentir correção, para o próprio desenvolvimento adequado do modelo.

Parece que convém amadurecer a experiência do modelo legal para exigir das entidades candidatas à qualificação um tempo mínimo de atuação comprovada em sua área de atividade; por exemplo, três anos, como na legislação federal reguladora da concessão do título ou certificado de entidade de fins filantrópicos (Lei Orgânica da Assistência Social, Lei 8.742, de 08.12.93, c/c Decreto $\mathrm{n}^{0}$ 2.536, de 06.04.98). Evita-se assim, com prudente cautela, a existência de entidades ad hoc, sem maior consistência, como beneficiárias do título. Protege-se também o novo título, com essa simples medida, contra ensaios de erosão de sua credibilidade. Nas leis estaduais sobre a qualificação de entidades como organizações sociais essa exigência já tem sido admitida (v.g., Lei Complementar n. 846, de 4 de junho de 1998, do Estado de São Paulo, exige comprovação de prestação de serviços próprios há mais de cinco anos pela entidade candidata a qualificação como organização social).

Outra questão é exigir a existência de patrimônio ou qualificação técnica especial para a própria candidatura de uma entidade privada ao título de organização social. Se se trata de colocar em prática uma parceria, é preciso estimular o oferecimento de contrapartidas ao apoio do Estado, não parecendo suficiente considerar como contrapartida o simples desempenho de atividade de relevância pública.

Além disso, a lei das organizações sociais é omissa quanto à necessidade do Estado exigir no contrato de gestão com as organizações sociais contraprestação em termos de certo percentual de serviços gratuitos diretamente prestados ao cidadão, quando isso for cabível. Por exemplo, exigir a equivalência entre o valor das subvenções concedidas ou o valor do apoio em termos não financeiros oferecidos pelo Estado e a prestação de serviços gratuitos. 
A exigência de obrigatória previsão nos estatutos das entidades da participação de representantes do Poder Público no conselho de administração das organizações sociais, conquanto signifique forma inovadora de acompanhamento efetivo das entidades qualificadas, parece medida útil apenas para as entidades de grandes dimensões. Nas entidades de menor vulto, que não movimentem recursos expressivos, parece ser exigência de difícil operacionalização, além de onerosa para o Poder Público, geralmente carente de pessoal técnico qualificado.

Por fim, para evitar suspeições indevidas contra o título de organização social, seria importante utilizar preferencialmente a qualificação como instrumento de ampliação dos direitos e obrigações de entidades privadas de fins públicos, independentemente da extinção de entidades e órgãos públicos existentes.

É certo que estamos ainda numa fase inicial de implantação do título de organização social. É difícil para as entidades do terceiro setor tradicionais aceitarem conviver com todas as exigências estabelecidas no marco legal das organizações sociais. $O$ sistema de confiança recíproca entre entidades do terceiros setor e o Estado ainda está em fase de construção na matéria. O Estado muitas vezes desconfia das organizações existentes e prefere estimular a criação de novas entidades e as antigas organizações, por seu turno, muitas delas surgidas para combater o Estado autoritário afirmado a partir de 1964, desconfiam do Estado, acreditando que o modelo permite uma ingerência indevida do poder público na atividade cotidiana da entidade.

A lei federal até o momento não foi, talvez por tudo isso, utilizada para qualificar entidades antigas, independentemente do processo de extinção, por lei específica, de entidades públicas de funcionamento deficiente. É esse o caminho, entretanto, mais frutífero, mais estimulante, que o modelo das organizações sociais pode abrir.

\section{O título de organização da sociedade civil de caráter público}

A mais nova proposta de alteração do marco legal das organizações do terceiro setor no Brasil é o recentíssimo projeto de lei sobre organizações da sociedade civil de caráter público, que tenta também esvaziar na prática o título de utilidade pública (Projeto de Lei n. 4.690), apresentado pelo Poder Executivo Federal em 28 de julho de 1998). É interessante observar que esse projeto, nascido de uma ampla interlocução da Comunidade Solidária com as entidades do terceiro setor, adota boa parte das inovações da lei das organizações sociais.

A semelhança da nova proposta com o modelo normativo das organizações sociais é indiscutível. Primeiro, a idéia comum de concessão de uma sobre-qualificação (nova qualificação ou titulação jurídica para pessoas jurídicas privadas sem fins lucrativos). Segundo, a restrição expressa à distribuição pela entidade de lucros ou resultados, ostensiva ou disfarçada (através, por exemplo, de pagamento de salários acima do mercado). Terceiro, a identificação de áreas sociais de atuação das entidades como requisito de qualificação. Quarto, a exigência de existência de um conselho de fiscalização dos administradores da entidade (Conselho de Administração nas organizações sociais, Conselho fiscal ou órgão equivalente na proposta do novo título). Quinto, o detalhamento de exigências estatutárias para que a entidade 
possa ser qualificada. Sexto, a exigência de publicidade de vários documentos da entidade e a previsão de realização de auditorias externas independentes. Sétimo, a criação de um instrumento específico destinado a formação de um vínculo de parceria e cooperação das entidades qualificadas com o Poder Público (contrato de gestão, nas Organizações Sociais; termo de parceria, nas Organizações da Sociedade Civil de Caráter Público). Oitavo, a possibilidade de remuneração dos diretores da entidade que respondam pela gestão executiva, observado valores praticados pelo mercado (remuneração vedada pela legislação de utilidade pública). Nono, a previsão expressa de um processo de desqualificação e de sanções e responsabilidades sobre os dirigentes da entidade em caso de fraude ou atuação ilícita.

É certo que são introduzidas inovações valiosas no marco legal da entidade do terceiro setor não previstas na lei das organizações sociais. São os traços diferenciais do novo projeto, resumidos na relação seguinte:

1) além da previsão genérica dos "candidatos positivos", vale dizer, das entidades que podem ser qualificadas com o novo título, o que também consta da lei das organizações sociais, o projeto faz de forma inovadora a identificação dos "candidatos negativos", isto é, a especificação das entidades que não podem ser qualificadas como o título de organizações da sociedade civil de caráter público (art. $2^{2}$ );

2) especificação detalhada dos "candidatos positivos"; por exemplo, nas áreas de educação e saúde, consta exigência de que as entidades candidatas à qualificação tenham como objeto social a prestação de serviços integralmente gratuitos (art. $3^{\mathfrak{0}}$ );

3) exigência de observância pela entidade de procedimentos contábeis exigidos pelo regulamento do imposto de renda (art. $4^{2}$ );

4) embora não indique prazo mínimo de existência da entidade, projeto indiretamente exige prazo de atividade de no mínimo dois exercícios financeiros, pois obriga apresentação de documentos diversos, entre eles, "balanço patrimonial e demonstrativo dos resultados financeiros dos últimos dois anos" e "declaração de isenção do Imposto de Renda dos últimos dois exercícios" (art. 50);

5) fixação do prazo de trinta dias para deferimento ou indeferimento do pedido de qualificação e prazo de quinze dias para expedição do "certificado de qualificação da requerente como organização da sociedade civil de caráter público" (art. 6º);

6) expressa proibição de participação das entidades qualificadas em campanhas de caráter político-partidário ou eleitorais, sob quaisquer meios ou formas (art. 17);

7) admissão expressa da cumulação do título de organização da sociedade civil de caráter público com outros títulos jurídicos aplicados a pessoas jurídicas de direito privado sem fins lucrativos, mas por prazo determinado, por dois anos, findo o qual deve a entidade interessada na manutenção do novo título renunciar às qualificações anteriores ou perderá, automaticamente, o novo título (art. 19).

Mas também o projeto apresenta algumas lacunas e inconsistências que ainda podem ser corrigidas.

A mais séria inconsistência consta de uma disposição final, mais precisamente $o$ art. 19. Essa disposição enuncia o seguinte:

"Art. 19. As pessoas juridicas de direito privado sem fins lucrativos, qualificadas com base em outros diplomas legais, poderão qualificar-se como Organizações 
da Sociedade Civil de Caráter Público, desde que atendidos aos requisitos para tanto exigidos, sendo-lhes assegurada a manutenção simultânea dessas qualificaçōes, até dois anos contados da data de vigência desta Lei.

$\S I^{\varrho}$ Findo o prazo de dois anos, a pessoa jurídica interessada em manter a qualificação prevista nesta Lei deverá por ela optar, fato que implicará a renúncia automática de suas qualificações anteriores.

$\S 2^{\underline{o}}$ Caso não seja feita a opção prevista no parágrafo anterior, a pessoa jurídica perderá, automaticamente, a qualificação obtida nos termos desta Lei".

Entendo que o texto da norma referida é contraditório com os objetivos do novo título jurídico. Com efeito, como a maioria dos benefícios legais atuais, previstos em leis da União, dos Estados, do Distrito Federal e dos Municípios para as entidades do terceiro setor, pressupõem a qualificação das entidades como entidades de utilidade pública, esta norma serviria apenas para afastar do novo regime as entidades de fins comunitários autênticas, que dificilmente estariam dispostas a perder todos os beneficios atuais em nome de benefícios futuros e incertos. Trata-se de um risco sério. Melhor seria adotar postura exigente na qualificação das novas entidades e prever que elas terão benefícios e controles novos, mas que não perderão os benefícios previstos na legislação existente para as entidades de utilidade pública. Foi a fórmula utilizada na lei das organizações sociais. Aquelas entidades que adquirem o título de OS recebem, por força de lei, automaticamente, o título de utilidade pública. Isso faz do título de OS um plus, uma qualidade adicional à personalidade jurídica de entidades privadas de fins públicos, não um título concorrente que se deve optar. Fora isso, a disciplina sugerida criaria um paradoxo, pois, ao menos no período inicial de dois anos, as entidades qualificadas duplamente como de utilidade pública e organização da sociedade civil de caráter público teriam mais vantagens e benefícios do que, comparativamente, as entidades qualificadas há mais tempo como organizações da sociedade civil de caráter público.

É manifesta a preocupação do projeto com a redução da margem de discrição das autoridades administrativas na concessão do novo título. É um propósito positivo e louvável. Neste sentido, o projeto responde a um dos problemas mais conhecidos do título de utilidade pública. Essa diretriz é evidente, por exemplo, na disposição que trata de informar as hipóteses em que o pedido de qualificação será indeferido art. $\left.6^{\circ}, \S^{\circ}\right)$. Na prática, porém, o projeto deixa em aberto questōes importantes, como uma disciplina mais detalhada do processo administrativo de cassação do novo título, prescrevendo apenas que será assegurada a ampla defesa e o contraditório (art. $7^{\mathbf{a}}$ ), as hipóteses em que devem ser feitas auditorias por auditores externos independentes (art. $4^{\mathfrak{l}}$, VII,$c$ ) e as hipóteses em que cabe ao Poder Público dispensar a cláusula de inalienabilidade nos bens imóveis adquiridos com recursos provenientes da celebração do termo de parceria (art. 15).

Há também uma lacuna ou omissão relevante. É a questão sobre a liberação financeira dos recursos públicos vinculados aos termos de parceria. Não consta do projeto qualquer sanção ou limitação ao Poder Público relativamente ao cumprimento do acordado no termo de parceria. Neste ponto, conviria incluir pelo menos uma cláusula obrigando a liberação financeira dos recursos acordados, pactuados como contraprestação do Poder Público pelos serviços sociais prestados pelas entidades 
qualificadas, segundo o cronograma de desembolso previsto no termo de parceria. Procura-se evitar com essa medida situações de contingenciamento na liberação de recursos aprovados e previstos no orçamento, acordados no termo de parceria, essenciais ao cumprimento da cooperação. Norma com o mesmo sentido consta da lei das organizações sociais (art. $12, \S 1^{\mathfrak{Q}}$, da Lei n. 9.637, de 15 de maio de 1998).

Outra omissão é a autorização expressa, necessariamente legal, para que servidores públicos federais possam colaborar diretamente na atividade de organizações qualificadas por prazo certo. Não faz sentido ignorar as possibilidades que esse tipo de colaboração poderia ensejar. Existente a autorização, essa forma de colaboração poderia ou não ser utilizada, conforme o que dispusesse o termo de parceria.

Essas observações pontuais, no entanto, não recusam o merecimento das soluções dadas na regulação do novo título. Algumas das deficiências dos títulos de utilidade pública e organização social são superadas. É certo também que, paradoxalmente, algumas deficiências do novo título parecem encontrar resposta no título de organização social. O novo projeto, no entanto, por si mesmo, é sinal de que o tema continua a suscitar inquietação e retificaçōes sucessivas. Trata-se de projeto inovador e, por ser assim, admite com maior presteza correções e aperfeiçoamentos.

\section{Resumo}

A avaliação das propostas mais recentes de alteração do marco legal das entidades privadas de fins públicos no Brasil não pode prescindir de uma prévia consideração da crise do título de utilidade pública, qualificação tradicionalmente utilizada no país para as entidades do terceiro setor, bem como de uma análise das vantagens e desvantagens para as entidades do terceiro setor de receberem do Poder Público a concessão de títulos jurídicos especiais.

A crise do título de utilidade pública explica uma parte expressiva das inovaçōes contempladas no título de organização social e na proposta do título de organização da sociedade civil de caráter público. O título de organização social já recebeu consagração legislativa no âmbito da União e em diversos Estados da Federação. $O$ título de organização da sociedade civil de caráter público encontra-se em fase de discussão no Congresso Nacional.

Os dois títulos jurídicos, no entanto, devem ser avaliados também à luz das funções e dos riscos que envolve a própria concessão de títulos jurídicos como forma de diferenciação, padronização e controle pelo Poder Público da atividade de entidades privadas sem fins lucrativos que desempenham atividades de relevante valor social.

A análise isolada das propostas recentes, além disso, revela a influência decisiva dos projetos ou soluções normativas anteriores sobre as subseqüentes. São explorados os aspectos que aproximam e diferenciam os títulos de utilidade pública e de organização social e, adiante, o título de organização social e o título de organização da sociedade civil de caráter público. Essa análise revela que não se trata de uma evolução linear, mas um processo de retificação e incorporação sucessivo, quase circular, que pode ensejar hoje tanto o aperfeiçoamento do título de organização 
social quanto do título de organização da sociedade civil de caráter público e, eventualmente, do próprio título de utilidade pública.

Referência Bibliográfica

ATIENZA, Manuel. (1997), Contribución a una Teoria de la Legislación. Madrid, Editorial Civitas, S.A.

BARROSO LEITE, Celso. (1997), "Filantropia e Assistência Social", in: Carta Mensal, Rio de Janeiro, 43 (507), jun.

BRESSER PEREIRA, Luiz Carlos. (1996), Crise Econômica e Reforma do Estado no Brasil: para uma nova interpretação da América Latina, Trad. de Ricardo Ribeiro e Martha Jalkauska, São Paulo, Ed. 34.

(1997), "A Reforma do Estado nos anos 90: Lógica e Mecanismos de Controle", in: Cadernos MARE de Reforma do Estado, n. 1, Brasília, Ministério da Administração Federal e Reforma do Estado.

CHEVALliER, Jacques (1992), "A Racionalização da Produção Jurídica", Trad. Teresa Salis Gomes. In: Legislação - Cadernos de Ciência de Legislação, Lisboa, Instituto Nacional de Administração Pública, jan./mar., pp.09-23.

CUNILL GRAU, Nuria (1996), “A rearticulação das relações Estado-sociedade: em busca de novos significados”, in: Revista do Serviço Público, ano 47, vol. 120, n. 1, jan.-abr.

FERRAZ JR., Tércio Sampaio. (1980), Função Social da Dogmática Jurídica. São Paulo, Ed. Revista dos Tribunais.

(1994), Introdução ao Estudo do Direito: técnica, decisão, dominação, $2^{\mathrm{a}}$ ed. São Paulo, Ed. Atlas.

MODESTO, Paulo. (1997), "Reforma Administrativa e Marco Legal das Organizações Sociais no Brasil: As dúvidas dos juristas sobre o Modelo das Organizações Sociais", in: Revista de Direito Administrativo, Rio de Janeiro, 210, out./dez., pp.195-212; Revista do Serviço Público, Brasília, ano 48, n. 2, maio/ ago., pp. $27-57$.

OLIVEIRA, Anna Cyntia. (1996), Construindo um Marco Regulatório para a Consolidação do Setor Privado não Lucrativo e de Fins Públicos no Brasil. Estudo elaborado a pedido do Conselho COMUNIDADE SOLIDÁRIA, Brasília, original mimeografado, nov.

PEREIRA JR., JESSÉ TORRES. (1973), "A utilidade pública de associações privadas e das fundações de menores", in: Arquivos do Ministério da Justiça, Ano $X X X$, junho, n. 126. 